\title{
Intersections
}

Canadian Journal of Music

Revue canadienne de musique

\section{Caryl Clark, ed. The Cambridge Companion to Haydn. Cambridge: Cambridge University Press, 2005. 318 pp. ISBN 0-521-54107-7 (paperback)}

\section{Kate Galloway}

Volume 27, numéro 1, 2006

URI : https://id.erudit.org/iderudit/1013163ar

DOI : https://doi.org/10.7202/1013163ar

Aller au sommaire du numéro

Éditeur(s)

Canadian University Music Society / Société de musique des universités canadiennes

ISSN

1911-0146 (imprimé)

1918-512X (numérique)

Découvrir la revue

Citer ce compte rendu

Galloway, K. (2006). Compte rendu de [Caryl Clark, ed. The Cambridge Companion to Haydn. Cambridge: Cambridge University Press, 2005. 318 pp.

ISBN 0-521-54107-7 (paperback)]. Intersections, 27(1), 100-103.

https://doi.org/10.7202/1013163ar

All Rights Reserved (C) Canadian University Music Society / Société de musique des universités canadiennes, 2007
Ce document est protégé par la loi sur le droit d'auteur. L'utilisation des services d'Érudit (y compris la reproduction) est assujettie à sa politique d'utilisation que vous pouvez consulter en ligne.

https://apropos.erudit.org/fr/usagers/politique-dutilisation/ 


\section{BooK Reviews/ReCENSIONS}

Caryl Clark, ed. The Cambridge Companion to Haydn. Cambridge: Cambridge University Press, 2005. 318 pp. ISBN 0-521-54107-7 (paperback).

Edited by leading Haydn scholar Caryl Clark, The Cambridge Companion to Haydn offers an accessible introduction not only to Haydn's work but also to the cultural environment that informed his music. The Companion surveys Haydn's vast compositional output: symphonies, string quartets, keyboard sonatas and trios, sacred music, miscellaneous vocal genres, and operas. Contributors provide overviews on Haydn and his contemporaries, his working environments in Eisenstadt and Eszterháza, and the interconnections between humour and exoticism in Haydn's music. Additionally, the Companion includes chapters on the reception of Haydn's music, the exploration of performance practice, Haydn's posthumous reception, contemporary sound recordings, and the images of Haydn that have multiplied in written documentation and critique. This volume presents ideas, research and dialogue from some of the leading scholars in the field of eighteenth-century music studies.

The Cambridge Companion to Haydn is divided into four substantial themed sections and contains seventeen essays. Section one locates Haydn in contemporary critical context "through critical re-readings of canonic texts that deconstruct received opinion" (p. xii). Section two looks at two methods by which Haydn confronted societal anxieties concerning 'difference' during the Enlightenment period. The third section examines aspects of Haydn's ouvre, while the fourth presents new interpretive approaches to Haydn studies.

The first section, "Haydn in Context" contains four essays. In "A letter from the wilderness: revisiting Haydn's Esterházy environments", Rebecca Green discusses the impact of isolation on Haydn's compositions. In "Haydn's aesthetics", James Webster examines Haydn's letters and the "London Notebooks." In his contribution "First among equals", David Wyn Jones identifies recurring themes of innocence, isolation and originality in Haydn scholarship.

In "Haydn's career and the idea of the multiple audience", Elaine Sisman reveals how the social and cultural context of Haydn's career influenced the types of audience for whom he wrote. According to Sisman, Haydn discovered a need to adapt to a new set of expectations that had emerged and become prevalent during the eighteenth century-for vocational composers, their career opportunities, and the existence of the multiple types of audience they addressed (pp. 3-6). Sisman examines key primary and secondary source documents as evidence of Haydn's conceptions of the "different strands of his audience," and indicates that "what will emerge are new views of his [Haydn's] relationship with 
performers, of his attitudes towards connoisseurs and critics, and of his enduring desire to be widely understood" (p. 6).

The second part of the Companion, "Stylistic and Interpretive Contexts", provides two insightful essays that discuss methods of interpreting Haydn's music. Scott Burnham's "Haydn and humour" debates the nature of the 'comic spirit' (p. 63) in Haydn's compositional œuvre and discusses the devices Haydn employed to evoke humour in his compositions, particularly in his finales.

Matthew Head's essay, "Haydn's exoticisms: 'Difference' and the Enlightenment", argues that "a distinctive feature of composition during the European Enlightenment is that composers found ways of representing cultures and music different from their own" (p. 77). Head illustrates that Haydn's music incorporates a rich variety of national, popular, and folk influences, predominantly from northern and central Europe, in a way that "does not crudely "Other" such materials. That is, he doesn't present them simply as exotic curiosities" (p. 79). Instead, Haydn "treats them as topics and as melodies that can participate fully in the musical discourse. [T] he relationship between exoticism, as a construction of difference, and the national, regional, and peasant colors of Haydn's music is not clear-cut" because the boundaries, both national and ideological, between what was "European" and "non-European" were flexible and fluid during Haydn's time (p. 79). Head positions Haydn's use of exoticisms within the larger framework of artistic movements and fashions during the Enlightenment, which he illustrates through detailed analysis, discussion, and illustrative repertoire examples.

In the third and most substantial section, "Genres", the contributors explore not only Haydn's canonical works but also some of his lesser-known works and types of composition. David Schroeder, in "Orchestral Music: Symphonies and concertos", examines Haydn's symphonic output, articulating that Haydn developed the nature of the symphony and created a model for subsequent composers. In "The quartets", Mary Hunter discusses the evolution of Haydn's string quartet idiom. Michelle Fillion, in her contribution "Intimate expression for a widening public: the keyboard sonatas and trios" examines how Haydn composed keyboard music aimed at wide reception and international appeal while remaining "essentially a vehicle for private sentiment" (p. 126). In his essay "Sacred music", James Dack, an editor of Haydn's early masses in the Joseph Haydn Werke, discusses how Haydn's masses lost their original context and were transferred to the concert hall from their original, intended setting. In his second contribution, "The sublime and the pastoral in The Creation and The Seasons", James Webster provides an insightful discussion of the recurrence of the sublime and the pastoral in Haydn's oratorios. Katalin Komlós's "Miscellaneous vocal genres", discusses the significant dimensions of these genres, pinpointing the reasons for their popularity in Haydn's time and why, though long neglected in performance and scholarship, contemporary performers are now rediscovering them.

In this section of the book, Caryl Clark offers a much anticipated discussion of Haydn's opera repertoire entitled "Haydn in the theater: the operas". She provides a substantial background to these works, a significant part of his œuvre 
that has been neglected in Haydn and eighteenth-century scholarship. Clark focuses on Haydn's Italian operas since they were of central interest to his patrons and his audience in the second half of the eighteenth century. (Due to the paucity of surviving sources, it is difficult to study the early operas, especially Haydn's German Singspiel Der neue krumme Teufel dating from the 1750s (p. 176).) Clark discusses the intersections between the social and economic sphere within which Haydn worked. She notes that although he had not experienced opera productions in Vienna or outside of the country, all aspects of opera production factored significantly in Haydn's career at Ezsterháza. Clark's contribution is divided into four subsections, significant periods in Haydn's life that are organized to correspond with changes in his operatic output: "Occasional operas: 1762-76" during which years Haydn wrote operas to be performed for significant occasions at the Ezsterháza court, "1781-84" following the inauguration of the new opera house (which also marks Haydn's experimentation with larger works and fantastical themes), and "The London Opera", when Haydn was commissioned to write Italian opera for performance in London during his first London excursion. Clark's contribution revives and revisits Haydn's operatic repertoire, noting that Haydn's opera scores are just a fragment of the operatic experience and that "further assessment of Haydn's operatic achievement will continue to unfold in the theater" (p. 199).

The fourth section of the Companion, entitled "Performance and Reception" includes four essays that approach Haydn studies with new interpretive approaches, including performance studies, gender readings, changing contexts of symphonic performances, and reception "based on cultural orientation and technological mediation" (p. xii). In "A composer, his dedicatee, her instrument, and I: thoughts on performing Haydn's keyboard sonatas", Tom Beghin explores and illustrates some of the complex problems involved by drawing on his experience, historical narratives, and issues of authentic historic instruments and acoustic space. In the essay entitled "Haydn and posterity: the long nineteenth century", James Garrett discusses the "fluidity and plurality" (p. 227) of nineteenth-century images of Haydn in reception history and how these were institutionally and ideologically constructed. Melanie Lowe's intriguing contribution, "Recorded performances: a symphonic study" describes how musical meaning in a performance changes with the mode of transmission.

In the final section of the Cambridge Companion to Haydn, Lawrence Kramer, a leading scholar of the relationships of English literature and music, discusses Haydn reception history, particularly how the different images of Haydn have been constructed, presented and disseminated over time. In "The kitten and the tiger: Tovey's Haydn", Kramer examines two images that have endured in Haydn reception history. The first image is the nineteenth-century view of a "periwigged Papa Haydn" as "sturdy" and "cheerful" (p. 239). Perpetuated by E.T.A. Hoffmann and Wagner, who regarded Haydn as the "master artificer" and his music as "lacking in depth", this image furthered the Romantic stereotype of eighteenth-century music in general (p. 239). On the other hand, Donald Francis Tovey viewed Haydn as a compositional innovator of originality and expressive range, in contrast to the stagnant image of Haydn's work that was 
fostered during the nineteenth-century. Kramer "explore[s] in greater detail the image that Tovey created and to read it symptomatically as a means of coordinating musical aesthetics with social and cultural values" (p. 240). Kramer clearly articulates three central aspects of Tovey's image of Haydn: his originality (contextualizing his discussion with Bloomian views on anxiety and struggle), artistic and socially free creativity, and what Kramer terms "transformative play, wit, critique [and] whimsy" (p. 240).

The Cambridge Companion to Haydn provides the reader with a current and accessible introduction to Haydn studies. At the same time, it offers new approaches to the analysis of the musical, social and cultural environment that informed his work. The Companion is an ideal resource for academics and students as well as those who have an interest in expanding their knowledge of Haydn and his work. The Cambridge Companion to Haydn offers eclectic and fresh perspectives of Haydn's life, work and career. It is a valuable addition to the existing literature in the field of Haydn studies.

Kate Galloway

Nikolaus Bacht, ed. Music, Theatre and Politics in Germany: 1848 to the Third Reich. Aldershot: Ashgate, 2006. 315 pp. ISBN-10: 0-7546-5521-0 (hardcover).

Nikolaus Bacht compiled this book of fourteen essays to celebrate the sixtieth birthday of renowned Wagner scholar John Deathridge, and it comes at a time when the literature on the period from the late 1840s to the end of the Third Reich is already so vast that it is daunting even for the specialist, let alone the generalist or the student. My first reaction was, "Do we really need yet another book in this well-trodden field?", but the care that the editor and his contributors have bestowed on their project soon won me over. I found it an engaging read and I would highly recommend its use in the classroom because each essay strikes such a good balance between synoptic narrative and contextual detail that students will not feel chastised for lacking background knowledge. Equally, for the seasoned scholar and teacher there are both excellent overviews and striking new perspectives.

Methodologically the essays cover a broad spectrum from source studies and analyses (both musical and textual) to historiography, political history, criticism, and philosophy. It is an intergenerational effort in which both younger scholars and established researchers draw their inspiration from "political historians and philosophers who have realized soon after the period covered here that a better understanding of what happened in the first half of the twentieth century can only be hindered by a divide artificially separating it from the second half of the preceding century" (p. 2). The essays are grouped into five sections entitled 1) The New German School, 2) Wagnerian Politics, 3) The Politics of Reception, 4) An Excursus on Vienna, 5) Interwar Germany; but due to limitations of space I have selected four papers, one each from the 